\title{
VALIDASI METODE AANC UNTUK PENGUJIAN UNSUR Mn, Mg DAN Cr PADA CUPLIKAN SEDIMEN DI SUNGAI GAJAHWONG
}

\author{
Wisjachudin Faisal, Elin Nuraini \\ Pusat Teknologi Akselerator dan Proses Bahan BATAN \\ Jl. Babarsari Kotak Pos 6101 ykbb, Yogyakarta 55281
}

Diterima 7 Januari 2010, diterima dalam bentuk perbaikan 15 Januari 2010, disetujui 18 Januari 2010

\begin{abstract}
ABSTRAK
VALIDASI METODE AANC UNTUK PENGUJIAN UNSUR Mn, Mg DAN Cr PADA CUPLIKAN SEDIMEN SUNGAI GAJAHWONG. Telah dilakukan validasi unsur $\mathrm{Mn}, \mathrm{Mg}$ dan $\mathrm{Cr}$ menggunakan metoda AANC. Sebagai standar digunakan SRM NBS 8704 (Bufallo River Sediment), dengan kondisi operasi generator neutron optimum pada tegangan pemercepat $110 \mathrm{kV}$. Kalibrasi energi dan nomer salur dengan sumber standar diperoleh persamaan y = 1,034x $+151,21$. Dari hasil analisis kualitatif menunjukkan puncak $\mathrm{Cr}$ dan Mn terjadi penimbrungan (interferensi), sehingga hanya unsur Mg yang dapat dianalisis. Hasil analisis kandungan unsur Mg (SRM) diperoleh harga presisi = $95,53 \%$ dan akurasi $=94,88 \%$, sedangkan harga rerata ketidakpastian diperluas untuk berbagai lokasi $=0,233 \pm$ 0,012. Hasil analisis kandungan Mg pada berbagai lokasi di sepanjang sungai Gajahwong berkisar antara 85,41 103,55 ppm. Bila dibandingkan dengan penelitian sebelumnya menunjukkan kandungan unsur $\mathrm{Fe}$, Al dan Si jauh lebih tinggi dibanding kandungan Mg.
\end{abstract}

\begin{abstract}
VALIDATION OF FNAA METHOD FOR TESTING THE ELEMENTS OF Mn. Cr AND Mg ON THE GAJAHWONG RIVER SEDIMENT SAMPLE. Validation of elements of $\mathrm{Mn}, \mathrm{Cr}$ and $\mathrm{Mg}$ by using FNAA method has been performed. NBS SRM 8704 (Bufallo River Sediment), was used as the standard reference material, with the neutrons generator operating condition at the optimum voltage of $110 \mathrm{kV}$. Energy and channel number of calibration lines obtained with the standard equation as $y=1.034 x+151.21$. From the analysis of SRM, the results show that only Mg can be analyzed, because $\mathrm{Cr}$ and $\mathrm{Mn}$ are located at the same peak point (interferences), so that they can not be analyzed. From the analysis for Mg element (SRM), the precision and the accuration obtained are $95.53 \%$ and $94.88 \%$, while the average price of expanded uncertainty for the various locations is $0.233 \pm 0.012$. Mg content analysis result at various locations along the river Gajahwong ranging from $85.41-103.55 \mathrm{ppm}$. When compared with previous studies showing the elements ontent of $\mathrm{Fe}, \mathrm{Al}$ and $\mathrm{Si}$ is much higher than $\mathrm{Mg}$ content.
\end{abstract}

\section{PENDAHULUAN}

Dencemaran lingkungan terjadi bila daur materi dalam lingkungan hidup mengalami perubahan, sehingga keseimbangan dalam hal struktur maupun fungsinya terganggu. Ketidakseimbangan struktur dan fungsi daur materi terjadi karena proses alam atau juga karena perbuatan manusia. Dalam abad modern ini banyak kegiatan atau perbuatan manusia untuk memenuhi kebutuhan biologis dan kebutuhan teknologi sehingga banyak menimbulkan pencemaran lingkungan. Dalam usaha merubah lingkungan hidupnya ini manusia untuk meningkatkan kesejahteraan hidupnya dapat menimbulkan masalah yang disebut pencemaran. Manusia juga dapat merubah keadaan lingkungan yang tercemar akibat perbuatannya ini menjadi keadaan lingkungan yang lebih baik, menjadi keadaan seimbang, dapat mengurangi terjadinya pencemaran lingkungan, bahkan diharapkan untuk dapat mencegah terjadinya pencemaran. Pencemaran lingkungan tersebut perlu mendapat penanganan secara serius oleh semua pihak, karena pencemaran lingkungan dapat menimbulkan gangguan terhadap kesejahteraan, kesehatan, bahkan dapat berakibat terhadap jiwa manusia[1].

Sungai merupakan perairan terbuka yang kondisinya sangat dipengaruhi oleh alam sekitar. Sungai Gajahwong merupakan salah satu Sub Daerah Aliran Sungai Opak yang berada di Daerah Istimewa Yogyakarta, meliputi wilayah Kabupaten Sleman, Kodya Yogyakarta dan Kabupaten Bantul. Sebelum memasuki kota Yogyakarta, sungai Gajahwong melewati areal pertanian subur yang sangat luas dan kemungkinan besar limbah 
kimia pertanian akan masuk dan mencemari air sungai dari hulu sampai hilir. Setelah memasuki kota Yogyakarta, diprediksi akan terjadi peningkatan jumlah sumber pencemar, antara lain limbah dari rumah sakit, pabrik penyamakan kulit, pabrik susu bubuk, serta limbah rumah tangga. Pembuangan limbah ini lama kelamaan akan mencemari sungai tersebut, sehingga akan menyebabkan menurunnya kualitas air. Berbagai polutan yang berasal dari eksternalisasi limbah kegiatan industri, rumah sakit dan limbah rumah tangga dalam bentuk beragam senyawa kimia masuk ke sungai Gajahwong. Jika polutan tersebut melampaui nilai batas ambang akan mengganggu ekologi perairan. Pengawasan atau monitoring terhadap sungai Gajahwong diperlukan untuk menjaga kualitas air sungai Gajahwong yang masih banyak dimanfaatkan oleh masyarakat sekitarnya. Selain itu juga untuk mendukung program Prokasih (Program Kali Bersih) yang telah ditetapkan oleh Pemerintah Daerah Yogyakarta.

Untuk itu perlu metode analisis yang tepat dan dapat terselusur. Dalam hal ini agar supaya data analisis yang diperoleh memenuhi sistem mutu litbang, maka peralatan yang digunakan baik peralatan uji maupun peralatan ukur serta metode pengujian yang digunakan harus terverifikasi, terkalibrasi dan telah divalidasi sesuai program jaminan mutu litbang. Metode pengujian yang digunakan adalah metode standar atau metode yang dikembangkan tetapi sudah divalidasi dengan standar baku, misalnya Standard Reference Material (SRM), dengan demikian sistem mutu litbang harus disiapkan dan diterapkan sesuai pedoman KNAPPP 02-2007 ${ }^{[2,3]}$.

Sertifikasi sistem mutu laboratorium bertujuan untuk memberikan jaminan kepada pemakai jasa laboratorium bahwa hasil uji yang dihasilkan memiliki nilai ketepatan dan ketelitian yang baik dengan nilai ketidakpastian sekecil mungkin. Pusat Teknologi Akselerator dan Proses Bahan (PTAPB) BATAN mempunyai alat akselerator generator neutron yang telah banyak digunakan dalam analisis unsur maupun aplikasi yang lain dengan metode analisis aktivasi neutron cepat (AANC). Untuk itu kegiatan litbang AANC perlu dilakukan verifikasi alat uji, kalibrasi alat ukur, validasi metode dan pengukuran ketidakpastian. Hasil uji laboratorium dapat diakui kebenarannya jika telah memiliki sertifikat penilaian hasil uji atau telah terakreditasi oleh Badan Standarisasi Nasional (BSN). Persyaratan pokok yang harus dipenuhi oleh laboratorium terakreditasi mengacu pada ISO/IEC 17025-2005. Untuk mendukung kegiatan litbang AANC, maka peralatan harus memenuhi sistem mutu yang berlaku. Pelaksanaan program jaminan mutu litbang AANC sangat ditunjang dengan adanya laboratorium pengujian yang memadai dan dapat dipercaya hasil pengujiannya. Laboratorium yang handal harus memenuhi berbagai kriteria antara lain tenaga kerja yang profesional, sarana dan prasarana yang memadai, peralatan laboratorium yang handal, secara berkala dilakukan kalibrasi oleh yang berwenang, memiliki prosedur operasional yang baku, metode analisis yang mutakhir, mempunyai program jaminan mutu litbang AANC.

Penelitian ini menerapkan jaminan mutu pengujian unsur dan nilai ketidakpastiannya pada unsur $\mathrm{Mn}, \mathrm{Mg}$ dan $\mathrm{Cr}$ dalam cuplikan sedimen menggunakan metode AANC. Validasi meliputi presisi, akurasi, serta ketidakpastian.

Tujuan penelitian ini adalah mengetahui unjuk kerja pada pengujian kadar unsur $\mathrm{Mn}, \mathrm{Mg}$ dan $\mathrm{Cr}$ dan ketidakpastian pengukuran dengan metode AANC dalam cuplikan sedimen sesuai persyaratan akreditasi laboratorium akselerator generator neutron sesuai ISO 17025-2005. Kemudian diterapkan pada cuplikan sesungguhnya dalam hal ini adalah cuplikan sedimen di daeran aliran sungai Gajahwong. Unsur-unsur $\mathrm{Mn}, \mathrm{Mg}$ dan $\mathrm{Cr}$ perlu dianalisis, di samping karena permintaan pasar, juga karena secara teknis ada beberapa kriteria tingkat sifat racun yaitu ${ }^{[4]}$ :

1. Sangat beracun dapat menyebabkan kematian atau gangguan kesehatan yang tidak pulih dalam waktu singkat. Adapun logam yang termasuk katagori ini adalah : $\mathrm{Pb}, \mathrm{Hg}, \mathrm{Cd}, \mathrm{Cr}, \mathrm{As}, \mathrm{Sb}, \mathrm{Ti}, \mathrm{U}$, dan $\mathrm{Be}$,

2. Moderat, yaitu dapat mengakibatkan gangguan kesehatan baik yang dapat pulih maupun yang tidak dapat pulih dalam jangka waktu relatif lama. Adapun logam yang termasuk katagori ini adalah : $\mathrm{Ba}, \mathrm{Be}, \mathrm{Cu}, \mathrm{Au}, \mathrm{Li}$, $\mathrm{Mn}, \mathrm{Se}, \mathrm{Te}, \mathrm{Va}, \mathrm{Co}$, dan Rb.

3. Kurang beracun, logam ini dalam jumlah yang besar dapat menimbulkan gangguan kesehatan. Logam-logam yang termasuk katagori ini antara lain : $\mathrm{Bi}, \mathrm{Co}, \mathrm{Fe}, \mathrm{Ca}, \mathrm{Mg}, \mathrm{Ni}, \mathrm{K}, \mathrm{Ag}, \mathrm{Ti}, \mathrm{Zn}$.

4. Tidak beracun, yaitu tidak menimbulkan gangguan kesehatan, misal : $\mathrm{Na}, \mathrm{Al}, \mathrm{Sr}$ dan $\mathrm{Ca}$.

\section{METODOLOGI}

Alat akselerator generator neutron SAMES J-25 diaplikasikan pada metode analisis aktivasi neutron cepat (AANC), dengan sumber neutron 14,5 MeV dapat diperoleh dari akselerator generator neutron berdasarkan 
reaksi fusi $\mathrm{D}+\mathrm{T}$ atau ${ }^{2} \mathrm{H}+{ }^{3} \mathrm{H} \rightarrow{ }^{4} \mathrm{He}+\mathrm{n}$. Neutron cepat yang dihasilkan generator neutron tersebut dimanfaatkan untuk tujuan analisis unsur dalam bahan. Proses iradiasi dengan neutron cepat 14,5 MeV dari generator neutron dilakukan selama 30 menit dengan arus deutron $1000 \mu \mathrm{A}$, tegangan pemercepat generator neutron $110 \mathrm{kV}$. Setelah cuplikan diradiasi, kemudian dilakukan pencacahan dengan alat spektrometri gamma (AccuSpec) yang terdiri dari detektor HPGe atau Nal(TI), sumber tegangan tinggi, penguat awal, penguat, MCA (Accuspec), dan komputer sebagai monitor Pengukuran dengan metode relatif memerlukan cuplikan standar yang mengandung unsur yang akan ditentukan, yang jumlahnya telah diketahui dengan pasti. Cuplikan standar dan cuplikan yang diselidiki diiradiasi bersama-sama, sehingga mengalami paparan radiasi neutron yang sama besarnya. Dengan jalan membandingkan laju cacah cuplikan dan laju cacah standar dapat dihitung kadar unsur di dalam cuplikan (lihat rumus 2)

Cuplikan yang akan dianalisis diiradiasi dengan neutron cepat yang dihasilkan oleh akselerator generator neutron (GN). Inti atom unsur-unsur yang berada dalam cuplikan akan menangkap neutron dan berubah menjadi radioaktif. Untuk penentuan konsentrasi unsur dalam cuplikan dengan metoda AANC, digunakan rumus ${ }^{[5]}$ :

$$
C=\frac{m N_{A}}{B A} a \frac{\phi \sigma \varepsilon Y}{\lambda}\left(1-e^{-\lambda t a}\right) e^{-\lambda t d}\left(1-e^{-\lambda t c}\right)
$$

dengan $\phi \quad$ : fluks neutron, $\sigma$ : tampang lintang reaksi, $\lambda$ : tetapan peluruhan

$\mathrm{t}_{\mathrm{a}} \quad$ : waktu yang diperlukan untuk iradiasi, $\mathrm{t}_{\mathrm{d}}$ : waktu tunda (coolling time)

$t_{c} \quad$ : waktu yang diperlukan untuk pencacahan, $m$ : massa cuplikan

a : kelimpahan relatif isotop cuplikan

$N_{A}$ : bilangan Avogadro, $B_{A}$ : berat atom unsur cuplikan

Persamaan (1) tersebut dapat dipandang sebagai dasar dan persamaan akhir analisis aktivasi neutron cepat (AANC). Untuk penghitungan kadar/konsentrasi dalam penelitian ini digunakan metode relatif atau komparatif, maka diperlukan cuplikan standar SRM yang telah diketahui konsentrasi dengan pasti. Cuplikan standar dan cuplikan contoh uji (unknown) diaktivasi bersama-sama, sehingga mendapat paparan neutron yang sama, sehingga persamaan (1) dapat disederhanakan menjadi :

$$
m_{x}=\frac{C_{x}}{C_{s}} \times m_{s}
$$

dengan $m_{x}$ : berat unsur dalam contoh uji,

$\mathrm{m}_{\mathrm{s}}$ : berat cuplikan standar

$\mathrm{C}_{\mathrm{x}}$ : cacah pada contoh uji,

$\mathrm{C}_{\mathrm{s}}$ : cacah pada cuplikan stándar

\section{Identifikasi ketidakpastian}

Mengestimasi masing-masing komponen ketidakpastian sehingga ekivalen dengan simpangan baku (deviation standard) sesuai dengan faktor kesalahannya, maka dilakukan kuantifikasi masing-masing komponen ketidakpastian. Kategori komponen ketidakpastian dapat dibedakan menjadi dua tipe, yaitu A dan B. Tipe A merupakan komponen ketidakpastian yang berdasarkan data percobaan dan dihitung dari rangkaian pengamatan, sedangkan tipe B merupakan komponen ketidakpastian yang berdasarkan informasi yang dapat dipercaya (data sekunder), misalnya spesifikasi pabrik, data pustaka, atau data validasi metode.

Langkah selanjutnya menggabungkan komponen ketidakpastian baku untuk menghasilkan ketidakpastian baku gabungan. Penggabungan ini disesuaikan dengan persamaan atau rumus yang digunakan dalam perhitungan hasil pengukuran, maka persamaan umum untuk menggabungkan nilai ketidakpastian baku dari komponen-komponennya menjadi ketidakpastian gabungan $\left(\mu_{c}\right)$ sebagai berikut :

$$
\mu_{c}=\sqrt{\left(\frac{\partial C}{\partial x}\right)^{2}\left(\mu_{x}\right)^{2}+\left(\frac{\partial C}{\partial y}\right)^{2}\left(\mu_{y}\right)^{2}+\left(\frac{\partial C}{\partial z}\right)^{2}\left(\mu_{z}\right)^{2}}
$$


Mengidentifikasi dan menginventarisasi semua faktor yang dapat memberikan kontribusi kesalahan terhadap hasil akhir dalam bentuk cause and effect diagram, serta mengelompokkan faktor-faktor tersebut kedalam kategori komponen ketidakpastian seperti terlihat pada Gambar 1.

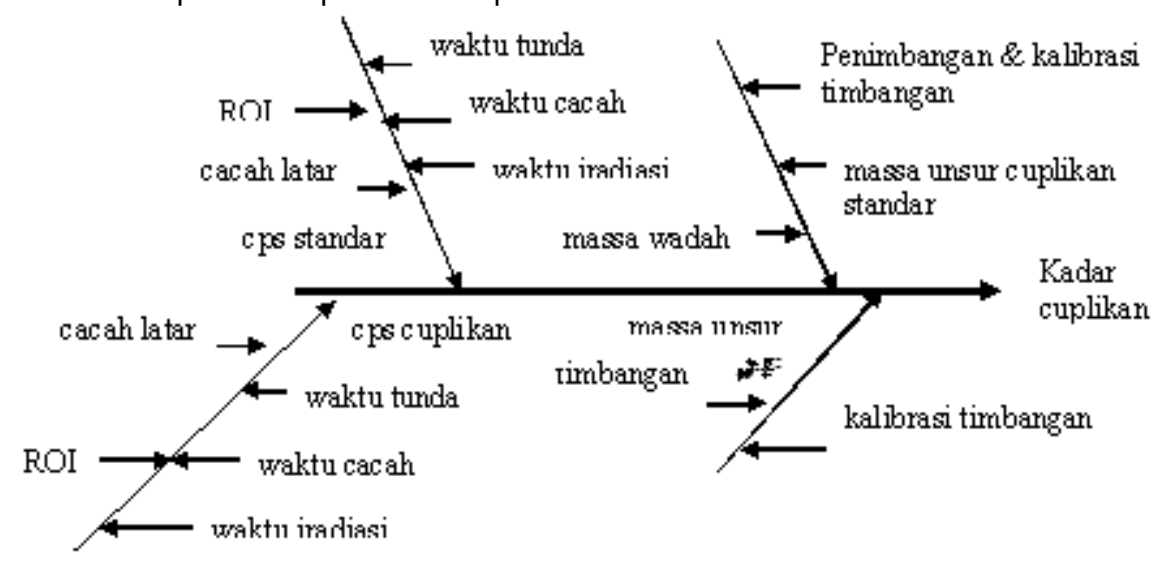

Gambar 1. Cause and Effect Diagram

Gambar 1 menunjukan faktor-faktor yang memberi kontribusi ketidakpastian pengukuran dalam metode AANC

\section{METODOLOGI}

\section{Alat dan bahan}

Unit generator neutron untuk mengaktivasi cuplikan, spektrometer gamma dengan detektor $\mathrm{Nal}(\mathrm{TI})$, timbangan analitik yang terkalibrasi, ampul polietilen, stopwatch terkalibrasi, timbangan analitis yang terkalibrasi. Cuplikan untuk validasi adalah standar (SRM 8704, Bufallo River Sediment), sedangkan cuplikan sedimen yang diteliti adalah sedimen yang diambil dari 7 titik sepanjang aliran sungai Gajahwong Yogyakarta. Ketujuh titik lokasi tersebut adalah : Ringroad utara, IAIN, SGM, pertigaan jalan Pramuka, Jembatan Rejowinangun, Winong dan Ringroad Selatan, sumber standar pemancar gamma Co-60, Cs-137, Eu-152.

\section{Preparasi cuplikan}

Cuplikan standar SRM 8704 ditimbang berkisar 1,0 gram sebanyak 10 buah. Cuplikan sedimen dibersihkan dari kotoran rumput, batu/kerikil, dikeringkan kemudian digerus hingga halus dan diayak sedemikian sehingga diperoleh cuplikan dengan ukuran tertentu (100 mesh) kemudian dihomogenkan dan ditimbang dengan berat kurang lebih 1,0 gram, kedua macam cuplikan tersebut dimasukkan dalaM ampul polietilen.

\section{Iradiasi dan Pencacahan}

Cuplikan sedimen dan standar SRM diaktivasi secara bersama-sama dengan neutron cepat menggunakan generator neutron selama 30 menit dengan arus ion $850 \mu \mathrm{A}$. Setelah itu isotop yang terbentuk dicacah dengan spektrometer gamma dengan detektor $\mathrm{Nal}(\mathrm{TI})$.

\section{Validasi Metode}

Kebenaran dan keabsahan hasil pengujian sangat tergantung pada kebenaran dan ketelitian alat ukur dan alat uji yang memenuhi sistem mutu pada pedoman KNAPPP 02-2007. Tujuan dari validasi metode ini agar hasil uji dari generator neutron dengan metode AANC menghasilkan hasil uji yang absah/valid yang meliputi presisi, akurasi dan batas deteksi. Jika diperoleh nilai akurasi, presisi, sensitivitas yang tinggi, berarti metode uji tersebut valid. Hasil uji dibandingkan dengan data yang tertera dalam data sertifikat.

Presisi menunjukkan kesesuaian antara beberapa pengulangan yang diukur dengan cara yang sama, dinyatakan dalam rumus ${ }^{[6]}$ :

$$
\text { Pr esisi }=\left(100-\left(\frac{S D}{H A} \times 100\right)\right) \%
$$


Nilai akurasi adalah kedekatan sebuah hasil analisis rata-rata dengan nilai sebenarnya (true value) atau besarnya penyimpangan data hasil uji dengan harga sesungguhnya. Nilai akurasi dapat dinyatakan :

$$
\text { Akurasi }=\left(100-\left(\frac{|\mathrm{HA}-\mathrm{KS}|}{\mathrm{KS}} \times 100\right)^{[6]}\right) \%
$$

KS : kadar Mg tercantum dalam sertifikat SRM ( \% )

$\mathrm{HA}$ : kadar Mg hasil analisis (\%)

\section{HASIL DAN PEMBAHASAN}

\section{Kalibrasi energi}

Untuk mencari hubungan antara nomor salur dan energi gamma diperlukan suatu kalibrasi energi dengan menggunakan sumber standar yang telah diketahui energinya. Sumber standar yang digunakan adalah ${ }^{137} \mathrm{Cs}$ dan ${ }^{60} \mathrm{Co}$ atau sumber standar yang lain. Hasil kalibrasi yang telah dilakukan diperoleh hubungan nomor salur dengan energi gamma berupa persamaan regresi dengan hasil $y=1,18 x+150,84$, harga $r=0,9999702$

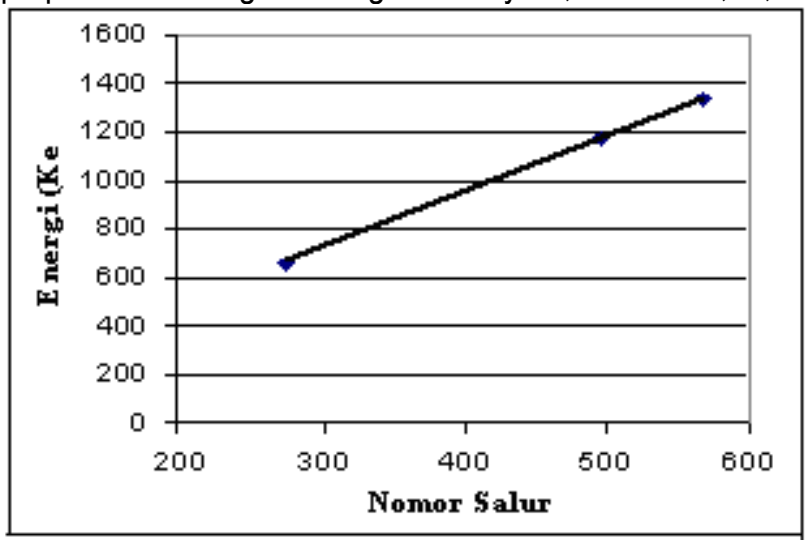

Gambar 2. Kurva nomor salur dan energi

\section{Kalibrasi efisiensi}

Hasil kalibrasi efisiensi menggunakan sumber standar Eu-152 diperoleh persamaan linier $y=10,205 x^{-0,9983}$ dengan tingkat korelasi koefisien $R^{2}=0,9727$.

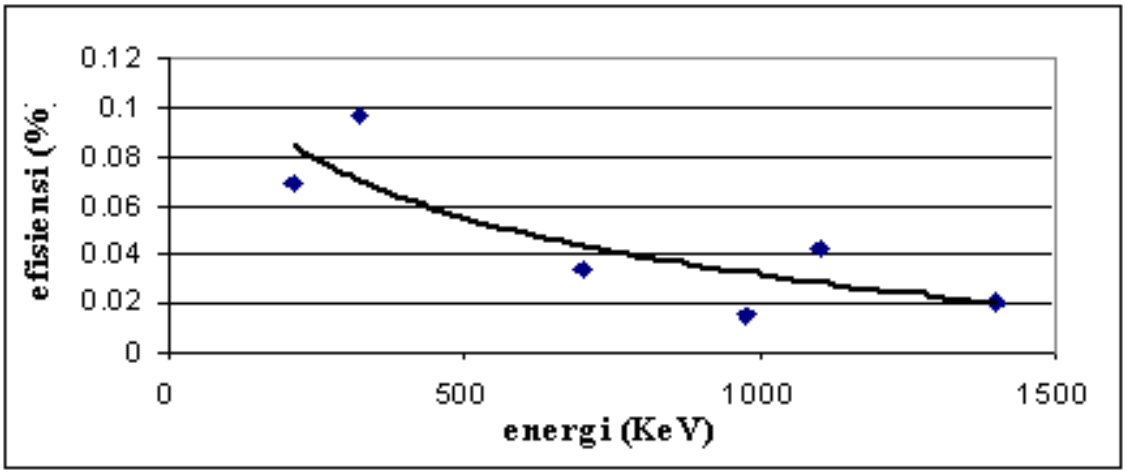

Gambar 3. Kurva kalibrasi efisiensi 


\section{Analisis Kualitatif}

Tabel 1. Data Nuklir dari Cr,Mg, $\mathrm{Mn}^{[7]}$

\begin{tabular}{|c|l|c|c|c|c|}
\hline Kelimpahan Isotop & Reaksi Isotop & $\mathbf{t}_{1 / 2}$ & Cross section & $\mathbf{E}$ & Yield \\
\hline 83,8 & ${ }^{52} \mathrm{Cr}(\mathrm{n}, \mathrm{p})^{52} \mathrm{~V}$ & 3,755 menit & $94 \mathrm{mb}$ & 1434,2 & 100 \\
& ${ }^{52} \mathrm{Cr}(\mathrm{n}, 2 \mathrm{n})^{51} \mathrm{Cr}$ & 27,71 hari & $318 \mathrm{mb}$ & 320,1 & 8,8 \\
\hline \multirow{3}{*}{100} & ${ }^{55} \mathrm{Mn}(\mathrm{n}, \mathrm{p})^{55} \mathrm{Cr}$ & 3,560 menit & $300 \mu \mathrm{b}$ & 1528,2 & 0,043 \\
& ${ }^{55} \mathrm{Mn}(\mathrm{n}, \mathrm{a})^{52} \mathrm{~V}$ & 3,755 menit & $110 \mu \mathrm{b}$ & 1434 & 100 \\
& ${ }^{55} \mathrm{Mn}(\mathrm{n}, 2 \mathrm{n})^{54} \mathrm{Mn}$ & 312,5 hari & $258 \mu \mathrm{b}$ & 834 & 100 \\
\hline 79 & $\left.{ }^{24} \mathrm{Mg}(\mathrm{n}, \mathrm{p})^{24 \mathrm{~m}} \mathrm{Na}\right)$ & 20,1 detik & $138 \mathrm{mb}$ & 1369 & 100 \\
& ${ }^{24} \mathrm{Mg}(\mathrm{n}, \mathrm{p})^{24} \mathrm{Na}$ & 15,02 jam & $190 \mathrm{mb}$ & 2754 & 100 \\
\hline
\end{tabular}

Dari hasil percobaan analisis kualitatif menunjukkan adanya permasalahan pada salah satu puncak $\mathrm{Cr}$ dan $\mathrm{Mn}$, keduanya tidak teridentifikasi dengan jelas, hal ini disebabkan karena kedua nuklida tersebut mempunyai nilai energi yang sangat berdekatan yaitu $1434 \mathrm{keV}$ dan $1434,2 \mathrm{keV}$ (t1/2 $=3,755$ menit) puncak kedua nuklida sudah barang tentu saling interferensi, sedangkan energi yang lain dari kedua nuklida tidak muncul. Untuk puncak Mn, pada energi $834 \mathrm{keV}$, karena nilai t1/2 cukup panjang, sehingga tidak terdeteksi, puncak nuklida $\mathrm{Cr}$ pada energi 320 harga yield relatif kecil sehingga puncaknya juga tidak terdeteksi. Puncak Mg hanya terdeteksi pada energi 1369 (Tabel 1).

\section{Validasi}

Tabel 2. Data hasil validasi metode uji AANC dengan cuplikan standar (SRM 8704)

\begin{tabular}{|c|c|c|c|c|c|c|}
\hline $\begin{array}{l}\text { Berat SRM } \\
\text { (gram) }\end{array}$ & $\begin{array}{c}\text { Kadar Mg } \\
\text { (gram) }\end{array}$ & Hasil uji (\%) & $\begin{array}{c}\text { Akurasi } \\
(\%)\end{array}$ & Presisi (\%) & $\begin{array}{c}\text { Selektifitas } \\
(\mathrm{keV})\end{array}$ & $\begin{array}{c}\text { Daerah kerja } \\
(\%)\end{array}$ \\
\hline 1,1175 & 0,0142 & 1,270 & \multirow{11}{*}{94,88} & \multirow{11}{*}{95,53} & \multirow{11}{*}{1369} & \multirow{11}{*}{$1,2 \pm 0,018$} \\
\hline 1,0348 & 0,0130 & 1,256 & & & & \\
\hline 1,0389 & 0,0134 & 1,290 & & & & \\
\hline 1,0132 & 0,0139 & 1,372 & & & & \\
\hline 1,0432 & 0,0133 & 1,275 & & & & \\
\hline 1,0321 & 0,0126 & 1,221 & & & & \\
\hline 1,0432 & 0,0123 & 1,179 & & & & \\
\hline 1,0643 & 0,0126 & 1,184 & & & & \\
\hline 1,1021 & 0,0141 & 1,279 & & & & \\
\hline 1,0321 & 0,0133 & 1,289 & & & & \\
\hline & Rerata & $1,2615 \pm 0,0537$ & & & & \\
\hline
\end{tabular}

Kebenaran dan keabsahan hasil pengujian sangat tergantung pada kebenaran dan ketelitian alat ukur dan alat uji yang memenuhi sistem mutu pada pedoman KNAPPP 02-2007. Hasil uji kuantitatif yang diperoleh dibandingkan dengan data dalam sertifikat. Hasil pengujian validasi terhadap unsur $\mathrm{Mg}$, seperti terlihat pada Tabel 2.

Adapun perhitungan Akurasi dan Presisi adalah sebagai berikut:

$$
\begin{aligned}
& \text { Akurasi }=\left(100-\left(\frac{|\mathrm{HA}-\mathrm{KS}|}{\mathrm{KS}} \times 100\right)\right) \%=94,88 \% \\
& \text { Pr esisi }=\left(100-\left(\frac{\mathrm{SD}}{\mathrm{HA}} \times 100\right)\right) \%=95,53
\end{aligned}
$$

Dari cuplikan Mg pada 10 kali pengulangan diperoleh harga $=1,2615 \pm 0,0537 \%$, akurasi $=94,88 \%$, presisi $=$ $95,53 \%$ 
Validasi Metode AANC Untuk Pengujian Unsur Mn, Mg dan Cr Pada Cuplikan Sedimen di Sungai Gajahwong (Wisjachudin Faisal, dkk.)

\section{Ketidakpastian pengukuran}

Perhitungan ketidakpastian penentuan kadar unsur Mg dalam contoh uji dengan metode komparatif menggunakan standar pembanding SRM.

\section{Ketidakpastian dari timbangan ${ }^{[8]}$}

\begin{tabular}{|l|l|}
\hline & Nilaiketidakpastian $(\mu)$ \\
\hline Perbedaan maksimum pembacaan $1.10^{-5}$ & $5,810^{-7}$ \\
Keseragaman skala optik 0,00132 & $7,610^{-5}$ \\
Kalibrasi massa yang terpasang pada timbangan 0,0000047 & $2,710^{-7}$ \\
Unjuk kerja timbangan 0,00032 & $1,84710^{-5}$ \\
Ketidakpastian penimbangan 0,000053 & $3,0610^{-6}$ \\
\hline Ketidakpastian $(\mu)$ total $=\sqrt{\left(5,810^{-7}\right)^{2}+\left(7,610^{-5}\right)^{2}+\left(2,710^{-7}\right)^{2}+\left(1,84710^{-5}\right)^{2}+\left(3,0610^{-6}\right)^{2}}$ \\
$=7,8310^{-5}$
\end{tabular}

\section{Ketidakpastian massa $\left(m_{\mathrm{x}}\right.$ dan $\left.\mathrm{m}_{\mathrm{s}}\right)$}

\begin{tabular}{|l|l|}
\hline & Nilai ketidakpastian $(\mu)$ \\
\hline Kontribusi dari timbangan & $7,8310^{-5}$ \\
Repeatibilitas penimbangan sebanyak 10 kali & $1,54310^{-4}$ \\
Ketidakpastian kalibrasi $\left[{ }^{[8]}=0,0014\right.$ & $8,110^{-5}$ \\
Massa contoh uji $\left(m_{x}\right)$ rata-rata $=0,27117 \pm 0,017 \mathrm{gr}$ & 0,00019 \\
Massa total standar $\left(m_{s}\right)$ rata-rata $=0,26721 \pm 0,023 \mathrm{gr}$ & 0,00019 \\
\hline Ketidakpastian $\left(\mu \mathrm{m}_{\mathrm{x}}\right)$ total $=\sqrt{\left(7,8310^{-5}\right)^{2}+\left(1,54310^{-4}\right)^{2}+\left(8,110^{-5}\right)^{2}}=0,00019$ \\
Ketidakpastian $\left(\mu \mathrm{m}_{\mathrm{s}}\right)$ total $=\sqrt{\left(7,8210^{-5}\right)^{2}+\left(1,54310^{-4}\right)^{2}+\left(8,110^{-5}\right)^{2}}=0,00019$ \\
\hline
\end{tabular}

\section{Ketidakpastian dari stopwatch ${ }^{[0]}$}

\begin{tabular}{|l|l|}
\hline & Nilai ketidakpastian $(\mu)$ \\
\hline Penunjukan alat 60,020 menit dengan ralat 0,162 & 0,0935 \\
Perbedaan kondisi ruang dengan data sertifikat $4^{0} \mathrm{C}$ & $4,0.10^{-4}$ \\
\hline Ketidakpastian $(\mu)$ total $=\sqrt{(0,0935)^{2}+\left(4,010^{-4}\right)^{2}}=0,0935$ & \\
\hline
\end{tabular}

\section{Ketidakpastian terhadap waktu}

\begin{tabular}{|l|l|}
\hline & Nilai ketidakpastian $(\mu)$ \\
\hline Kontribusi dari stopwatch & 0,0935 \\
Waktu iradiasi sampel dan stnadar bersamaan & $\begin{array}{l}\text { diabaikan } \\
2,0.10^{-4}\end{array}$ \\
Waktu tunda untu duplo pengukuran & \\
\hline Ketidakpastian $(\mu)$ total $=\sqrt{(0,0935)^{2}+\left(2,010^{-4}\right)^{2}}=0,09358$ & \\
\hline
\end{tabular}

\section{Aktivitas cuplikan $\left(C_{\mathrm{s}}, \mathrm{C}_{\mathrm{x}}\right)$}

\begin{tabular}{|c|c|c|}
\hline & Aktivitas cuplikan $\left(\mathrm{C}_{\mathrm{x}}\right)$ & Aktivitas standar $\left(\mathrm{C}_{\mathrm{s}}\right)$ \\
\hline Aktivitas & $3,07 \pm 0,34$ & $373,79 \pm 0,12$ \\
\hline Akt. blanko & $2,20 \pm 0,005$ & $2,20 \pm 0,005$ \\
\hline Pulse pile up & $140,78 \pm 0,008$ & $140,78 \pm 0,008$ \\
\hline \multicolumn{3}{|c|}{ Ketidakpastian total $\left(\mu \mathrm{C}_{\mathrm{x}}\right)$ unsur Mg adalah $=\sqrt{(0,09358)^{2}+(0,34)^{2}+(0,005)^{2}+(0,008)^{2}}=0,3527$} \\
\hline \multicolumn{3}{|c|}{ Ketidakpastian total $\left(\mu \mathrm{C}_{\mathrm{s}}\right)$ unsur Mg standar $=\sqrt{(0,09358)^{2}+(0,12)^{2}+(0,005)^{2}+(0,008)^{2}}=0,1525$} \\
\hline
\end{tabular}




\section{Ketidakpastian standar CRM ${ }^{[10]}$}

\begin{tabular}{|l|l|}
\hline & Nilai ketidakpastian $(\mu)$ \\
\hline $\operatorname{Kadar}\left(\mathrm{w}_{\mathrm{s}}\right)$ Mg standar $(1,2 \pm 0,018) \%$ & $0,018 / \sqrt{3}=0,0104$ \\
\hline
\end{tabular}

Menghitung kadar yang terkandung dalam cuplikan $\left(m_{x}\right)$ dalam hal ini $\mathrm{Mg}$

$$
\mathrm{m}_{\mathrm{x}}=\frac{\mathrm{C}_{\mathrm{x}}}{\mathrm{C}_{\mathrm{s}}} \times \mathrm{m}_{\mathrm{s}}=\frac{3,07}{373,79} \times 1,2=0,009856 \%
$$

\section{Ketidakpastian gabungan}

$$
\begin{aligned}
\mu \mathrm{c} & =\sqrt{\left(\mu \mathrm{C}_{\mathrm{x}} / \mathrm{C}_{\mathrm{x}}\right)^{2}++\left(\mu \mathrm{C}_{5} / \mathrm{C}_{5}\right)^{2}+\left(\mu \mathrm{m}_{5} / \mathrm{Cm}_{5}\right)^{2}+\left(\mu \mathrm{m}_{\mathrm{x}} / \mathrm{Cm}_{\mathrm{x}}\right)^{2}++\left(\mu \mathrm{w}_{5} / \mathrm{Cw}_{5}\right)^{2}} \\
& =\sqrt{(0,3527 / 3,07)^{2}+(0,1525 / 373,79)^{2}+(0,00019 / 0,26721)^{2}+(0,00019 / 0,27117)^{2}+(0,0104 / 1,2)^{2}} \\
& =0,115
\end{aligned}
$$

Ketidakpastian diperluas $0,115 \times 2=0,230$

Sehingga $m_{x}=(98,56 \pm 0,230) p p m$

Untuk cuplikan yang lain, karena lokasi pencuplikannya berbeda maka harus dihitung tersendiri ketidakpastiannya. Setelah dihitung dengan cara yang sama maka hasil ketidakpastiannya dapat dilihat pada Tabel 3.

Dari perhitungan ketidakpastian pada masing-masing lokasi tersebut, diperoleh rerata dari perhitungan rerata ketidakpastian diperluas unsur $\mathrm{Mg}$ adalah $0,233 \pm 0,012$ dan nilai rerata ketidakpastian relatif $=0,252 \pm$ $0,030 \%$, nilai tersebut termasuk ketidakpastian relatif cukup baik. Nilai ketidakpastian juga menyatakan mutu hasil pengukuran atau pengujian, semakin kecil nilai ketidakpastian maka semakin baik hasil penelitian atau pengujian.

Nilai ketidakpastian tersebut diakibatkan adanya kesalahan random dan kesalahan sistemik. Kesalahan random yaitu kesalahan yang terjadi tanpa disengaja, bervariasi dari satu uji ke uji berikutnya. Kesalahan random sulit dihindari karena disebabkan oleh fluktuasi yang tidak diduga-duga ${ }^{[11,15]}$. Sedangkan kesalahan sistemik berupa kesalahan yang ditimbulkan oleh adanya faktor tetap yang mengakibatkan data hasil uji cenderung lebih tinggi atau lebih rendah dari harga yang sesungguhnya. Kesalahan sistemik dapat disebabkan oleh kesalahan kalibrasi, kesalahan titik nol, kelelahan komponen alat, gesekan dan kondisi ruang saat bekerja $[12,15]$.

Dari Tabel 3 terlihat bahwa kandungan unsur logam Mg di berbagai lokasi di sepanjang sungai Gajahwong berkisar antara 85,41 hingga $103,55 \mathrm{ppm}$. Dari hasil analisis terdahulu ${ }^{[14,15]}$ analisis beberapa unsur pada berbagai lokasi di sepanjang sungai Gajahwong menunjukkan kandungan unsur $\mathrm{Fe}$, Al dan Si masing-masing berkisar antara 1,76-4,68 \%, 1,48-8,15\% dan 1,22 -14,11\%. Dari data tersebut menunjukkan bahwa kandungan $\mathrm{Fe}$, Al dan Si jauh lebih tinggi dibanding kandungan Mg yang kadarnya dalam orde ppm.

Tabel 3. Kandungan Mg pada berbagi lokasi disepanjang Sungai Gajahwong

\begin{tabular}{|l|c|c|}
\hline \multirow{2}{*}{ Lokasi } & Kadar (ppm) dan ketidakpastian & Ketidakpastian relatif (\%) \\
\cline { 2 - 3 } & $\mathbf{M g}$ & \\
\hline 1. J.Ring Road utara & $98,56 \pm 0,230$ & 0,233 \\
\hline 2. J.UIN & $98,97 \pm 0,217$ & 0,219 \\
\hline 3. J.SGM & $103,55 \pm 0,213$ & 0,206 \\
\hline 4. J.Rejowinangun & $92,32 \pm 0,238$ & 0,258 \\
\hline 5. J.Jl.Pramuka & $87,53 \pm 0,241$ & 0,275 \\
\hline 6. J.Winong & $85,94 \pm 0,243$ & 0,283 \\
\hline 7. J.Ring Road Selatan & $85,41 \pm 0,247$ & 0,289 \\
\hline \multicolumn{1}{|c|}{ Rerata ketidakpastian } & $0,233 \pm 0,012$ & $0,252 \pm 0,030$ \\
\hline
\end{tabular}


Validasi Metode AANC Untuk Pengujian Unsur Mn, Mg dan Cr Pada Cuplikan Sedimen di Sungai Gajahwong (Wisjachudin Faisal, dkk.)

Tabel 4. Data kuantitatif unsur yang terkandung dalam sampel sedimen ${ }^{[1,15]}$

\begin{tabular}{|l|c|c|c|}
\hline \multirow{2}{*}{ Lokasi } & \multicolumn{3}{|c|}{ Kadar (\%) } \\
\cline { 2 - 4 } & $\mathbf{F e}$ & $\mathbf{A l}$ & $\mathbf{S i}$ \\
\hline 1. J.Ring Road utara & 1,90 & 3,47 & 14,11 \\
\hline 2. J.UIN & 4,68 & 2,05 & 4,59 \\
\hline 3. J.SGM & 1,36 & 2,49 & 1,22 \\
\hline 4. J.Rejowinangun & 4,54 & 1,48 & 3,78 \\
\hline 5. J.Jl.Pramuka & 2,52 & 3,01 & 4,67 \\
\hline 6. J.Winong & 1,78 & 2,36 & 2,26 \\
\hline 7. J.Ring Road Selatan & 2,46 & 8,15 & 12,75 \\
\hline
\end{tabular}

Demikian halnya bila ditinjau nilai ketidakpastian relatif, nilai $\mathrm{Mg}$ jauh lebih kecil dibanding $\mathrm{Fe}, \mathrm{Al}$ dan $\mathrm{Si}$. (Tabel 3 dan Tabel 5). Nilai ketidakpastian menunjukkan mutu hasil pengukuran atau pengujian, semakin kecil nilai ketidakpastian maka semakin baik hasil penelitian atau pengujian.

Bila ditinjau kandungan logam-logam lain selain Mg di sepanjang sungai Gajahwong, maka dari Tabel $4^{[14]}$ terlihat bahwa kandungan unsur Al pada lokasi jembatan Ring Road Utara dan jembatan Ring Road Selatan mempunyai kadar yang lebih tinggi dibandingkan lokasi yang lain. Hal tersebut diduga diakibatkan oleh limbah dari percetakan serta limbah pabrik yang berasal dari serpihan Al dalam cat, maupun limbah rumah tangga yang berasal dari peralatan dapur, sedangkan kandungan unsur Fe kemungkinan berasal dari pasir besi yang secara alami sudah ada pada dasar sungai yaitu karena pelapukan dari batuan basa yang mengandung besi. Disamping itu Fe sangat boleh jadi berasal dari limbah rumah tangga atau dari hotel, maupun limbah rumah sakit yang berasal dari sisa obat atau darah. Kadar logam tertinggi terdapat pada lokasi J.Rejowinangun dan J.UIN yang disekitarnya banyak terdapat pemukiman warga dan Rumah Sakit, sedangkan pada lokasi lain logam ini terdistribusi dengan nilai kadar cukup rendah. Kandungan logam Si terlihat bahwa unsur ini tersebar merata pada semua lokasi pengambilan dengan kadar unsur yang cenderung acak. Kadar tertinggi terletak pada lokasi J.Ring Road utara dan J.Ring Road Selatan. Hal tersebut dikarenakan pada lokasi ini mempunyai kondisi sungai yang dangkal dan berpasir. Seperti telah dijelaskan sebelumnya bahwa Si merupakan komponen dasar dari pasir. Lokasi J.SGM mempunyai kondisi tanah yang berlumpur sehingga menyebabkan kadar yang rendah. Bila hal tersebut di atas dibandingkan dengan kandungan Mg, maka dari Tabel 3 terlihat bahwa di berbagai lokasi di sepanjang sungai Gajahwong ternyata relatif tidak berbeda secara signifikan, hanya di lokasi 3 (J.SGM) relatif agak lebih tinggi dibanding dengan lokasi lainnya, hal ini dimungkinkan kandungan Mg ini berasal dari limbah pupuk pertanian dan limbah Rumah Sakit disekitar lokasi. Menurut para pakar logam Mg termasuk logam yang kurang beracun sehingga kisaran di atas masih di bawah dari jumlah yang dapat mengganggu kesehatan. Logam $\mathrm{Mg}$ atau magnesium sering digunakan sebagai agen pereduksi dalam produksi uranium murni dan logam-logam lain dari garam-garamnya. Keracunan magnesium sangat jarang terjadi ${ }^{[12]}$. Beberapa faktor yang dapat mempengaruhi kadar suatu logam dalam sedimen yaitu, ukuran endapan yang masuk ke dalam aliran badan sungai, tingkat kekasaran dasar sungai, kemiringan sungai dan debit air sungai. Semakin tinggi kadar logam pada sungai maka akan berakibat terjadi pencemaran lingkungan dan dapat merusak ekosistem yang ada.

Tabel 5. Hasil Perhitungan ketidakpastian relatif unsur Fe, Al, Si ${ }^{[15]}$

\begin{tabular}{|l|c|c|}
\hline No & Unsur & Ketidakpastian relatif \\
\hline 1 & $\mathrm{Fe}$ & $(3,42) \%$ \\
2 & $\mathrm{Al}$ & $(1,22) \%$ \\
3 & $\mathrm{Si}$ & $(3,65) \%$ \\
\hline
\end{tabular}

Dari hasil analisis yang telah dilakukan ternyata unsur $\mathrm{Cr}$ dan $\mathrm{Mn}$ tidak terdeteksi, sehingga diharapkan pada penelitian yang akan datang analisis unsur $\mathrm{Cr}$ dan Mn dapat dilakukan dengan metode AANI (Analisis Aktivasi Neutron Instrumental) yaitu mereaksikan unsur tersebut dengan neutron termal (dari Reaktor Kartini), 
karena pada kenyataannya bila direaksikan dengan neutron cepat (AANC) terdapat beberapa kendala yang telah dijelaskan di muka.

\section{KESIMPULAN}

Hasil analisis kandungan unsur Mg (SRM) diperoleh harga presisi $=95,53 \%$ dan akurasi $=94,88 \%$, sedangkan harga rerata ketidakpastian diperluas untuk berbagai lokasi $=0,233 \pm 0,012$. Hasil analisis kandungan Mg pada berbagai lokasi di sepanjang sungai Gajahwong berkisar antara 85,41 - 103,55 ppm. Bila dibandingkan dengan penelitian sebelumnya menunjukkan kandungan unsur $\mathrm{Fe}, \mathrm{Al}$ dan Si yang masing-masing berkisar antara 1,76-4,68 \%, 1,48 - 8,15\% dan 1,22 -14,11\%, demikian juga nilai ketidakpastian relatif jauh lebih tinggi dibanding kandungan $\mathrm{Mg}$ yang kandungannya dalam orde ppm. Analisis $\mathrm{Cr}$ dan $\mathrm{Mn}$ pada penelitian lanjutan akan dilakukan dengan mereaksikan unsur tersebut dengan neutron termal (di Reaktor Kartini) yaitu dengan metode Analisis Aktivasi Neutron Instrumental.

\section{DAFTAR PUSTAKA}

1. ACHMAD LUTFI, http://www.chem-is-try.org/ (2009).

2. Pedoman KNAPPP 02-2007, tentang, Persyaratan Umum Kompetensi Pranata Penelitian dan Pengembangan (2007).

3. BSN, Persyaratan Umum Kompetensi Laboratorium Pengujian dan Laboratorium Kalibrasi, SNI -170252005 (2006).

4. MARTONO, S., , "Dampak Limbah Terhadap Lingkungan" bahan Diskusi Kursus Singkat Penanganan Limbah Secara Hayati.( 1977)

5. NARGOLWALLA, SAM..S. et.al, "Activation Analysis with Neutron Generators", John Wiley and Sons, New York (1973).

6. C. MILLER AND J.N. MILLER, Statistic for Analitical Chemistry, Ellis Horwood Limited, First published, (1984)::

7. GERHARD ERDTMANN, "Neutron Activation Tables," Kernchemie in Einzeldarstellungen Vol.6, Weinheim Verlag Chemie, New York, (1976).

8. Sertifikat Kalibrasi Timbangan Mekanik, Indocal Laboratori System, Bandung, (2005).

9. Sertifikat Kalibrasi Stopwatch, Departemen Perdagangan RI., Direktorat Jenderal Perdagangan Dalam Negeri, Bandung, Nopember, (2005).

10. ANONIM, NATIONAL INSTITUTE OF STANDARD \& TECHNOLOGY, Certificate Reference Material 8704, Buffalo River Sediment, (2000).

11. B. DARMAWAN DJONOPUTRO, Teori Ketidakpastian Menggunakan Satuan SI, Terbitan Kedua, ITB, Bandung, (1984)

12. JULIA KANTASUBRATA, Dasar Ketidakpastian Pengukuran, Pusat Penelitian Kimia-LIPI, Jakarta, (2003)

13. ANONIM, "http://ms.wapedia.mobi/ms/Manganese (2008)

14. AGUS T., ELIN N., SUNARDI "Distribusi Unsur Dalam Sedimen Sungai Gajahwong Daerah Hulu Hilir Dengan AANC", Prosiding PPI TeknoVol 10, Oktober 2008, ISSN 1411-1349 (2008)

15. SUNARDI,"Estimasi Ketidakpastian Pengujian Cu, Fe, Al, Si, Dalam Sedimen Dengan Metode AANC, Prosiding Pertemuan IImiah Litbang Teknologi Akselerator Dan Proses Bahan, Yogyakarta 23 Desember 2008 (2008). 